November 1999 - NREL/CP-520-26922

\title{
Current Status and Future Prospects for the PVMaT Project
}

C.E. Witt, R.L. Mitchell, M. Symko-Davies, and H.P. Thomas

National Renewable Energy Laboratory

R. King

U.S. Department of Energy

D.S. Ruby

Sandia National Laboratories

Presented at the $11^{\text {th }}$ International Photovoltaic Science and Engineering Conference (PVSEC-11)

Sapporo, Japan

September 20-24, 1999
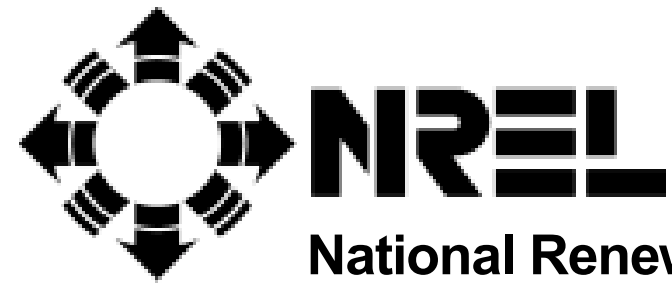

National Renewable Energy Laboratory

1617 Cole Boulevard

Golden, Colorado 80401-3393

NREL is a U.S. Department of Energy Laboratory

Operated by Midwest Research Institute $\bullet$ Battelle $\bullet$ Bechtel

Contract No. DE-AC36-98-G010337 


\section{NOTICE}

The submitted manuscript has been offered by an employee of the Midwest Research Institute (MRI), a contractor of the US Government under Contract No. DE-AC36-99G010337. Accordingly, the US Government and MRI retain a nonexclusive royalty-free license to publish or reproduce the published form of this contribution, or allow others to do so, for US Government purposes.

This report was prepared as an account of work sponsored by an agency of the United States government. Neither the United States government nor any agency thereof, nor any of their employees, makes any warranty, express or implied, or assumes any legal liability or responsibility for the accuracy, completeness, or usefulness of any information, apparatus, product, or process disclosed, or represents that its use would not infringe privately owned rights. Reference herein to any specific commercial product, process, or service by trade name, trademark, manufacturer, or otherwise does not necessarily constitute or imply its endorsement, recommendation, or favoring by the United States government or any agency thereof. The views and opinions of authors expressed herein do not necessarily state or reflect those of the United States government or any agency thereof.

Available electronically at http://www.doe.gov/bridge

Available for a processing fee to U.S. Department of Energy and its contractors, in paper, from:

U.S. Department of Energy

Office of Scientific and Technical Information

P.O. Box 62

Oak Ridge, TN 37831-0062

phone: 865.576 .8401

fax: 865.576.5728

email: reports@adonis.osti.gov

Available for sale to the public, in paper, from:

U.S. Department of Commerce

National Technical Information Service

5285 Port Royal Road

Springfield, VA 22161

phone: 800.553 .6847

fax: 703.605.6900

email: orders@ntis.fedworld.gov

online ordering: http://www.ntis.gov/ordering.htm

Printed on paper containing at least $50 \%$ wastepaper, including $20 \%$ postconsumer waste 


\title{
Current Status and Future Prospects for the PVMaT Project
}

\author{
C. Edwin Witt, ${ }^{1}$ Richard L. Mitchell, ${ }^{1}$ Martha Symko-Davies, ${ }^{1}$ \\ Holly P. Thomas, ${ }^{1}$ Richard King, ${ }^{2}$ and Douglas S. Ruby ${ }^{3}$ \\ ${ }^{1}$ National Renewable Energy Laboratory \\ MS-3214, 1617 Cole Blvd., Golden, CO, 80401, USA \\ ${ }^{2}$ U.S. Department of Energy, EE-131 \\ 1000 Independence Avenue SW, Washington DC, 20585, USA \\ ${ }^{3}$ Sandia National Laboratories \\ Albuquerque, NM, 87185-0752, USA
}

\begin{abstract}
The goals of the Photovoltaic Manufacturing Technology project (PVMaT) are to help the U.S. PV industry improve photovoltaic manufacturing processes and equipment; accelerate manufacturing cost reductions for PV modules, balance-of-systems components, and integrated systems; increase commercial product performance and reliability; and enhance the investment opportunities for substantial scale-ups of U.S.-based PV manufacturing plant capacities. PVMaT is in its ninth year of implementation, and subcontracts have been completed from four solicitations for R\&D on manufacturing process problems. We are in the second year of subcontracts for a fifth PVMaT solicitation.

Based on the latest (1998) data from ten PVMaT industrial participants, the average direct manufacturing cost for these producers has been reduced by $29 \%$ - from $\$ 4.08$ to $\$ 2.91$ per peak watt since 1992 - and there has also been a more than five-fold increase in manufacturing capacity-from 13.1 to 73.3 megawatts. We believe that continuing R\&D on manufacturing processes contributes significantly to expeditious reductions in PV manufacturing costs, and we identify areas for future R\&D.
\end{abstract}

\section{Introduction}

The Photovoltaic Manufacturing Technology project (PVMaT) is a government/industry research and development (R\&D) partnership. Its goals are to help the U.S. PV industry improve photovoltaic manufacturing processes and equipment; accelerate manufacturing cost reductions for PV modules, balance-of-systems components, and integrated systems; increase commercial product performance and reliability; and enhance the investment opportunities for substantial scale-ups of U.S.-based PV manufacturing plant capacities.

PVMaT is in its ninth year of implementation, and subcontracts have been completed from four solicitations for $\mathrm{R} \& \mathrm{D}$ on manufacturing process problems. These solicitations addressed, respectively, 1) process-specific $R \& D$ on $P V$ module manufacturing (open only to companies having competed successfully in a preliminary problem-definition phase), 2) generic research on problems of interest to all or to a large portion of the PV industry, 3) process-specific R\&D on PV module manufacturing (open to all U.S. companies), and 4) product-driven $P V$ manufacturing $R \& D$ addressing problems as in 2) and 3), as well as manufacturing improvements for balance-of-system (BOS) components and system design improvements. We are in the second year of subcontracts for a fifth PVMaT solicitation. As in the fourth solicitation, these efforts address a broad range of manufacturing problems, including BOS and system. In addition, we have encouraged $R \& D$ on improved methods of developing source materials, and several PV industry entities are studying ways to reduce active material costs. Fourteen subcontracts were awarded from this 1998 solicitation.

This paper describes recent accomplishments from the active subcontracts and provides a view of the PVMaT project status as a whole. The latter includes: 1) total project funding by PV technology, 2) cost-sharing by industry, 3) an analysis showing how the costs for PVMaT manufacturing R\&D have been recouped through reduced production costs by the industry and reduced prices to the customer, and 4) the overall achievement of the PVMaT cost and capacity objectives throughout the life of the project. Suggestions for future $R \& D$ areas are presented.

\section{Recent Accomplishments}

Recent accomplishments by the participants selected from the most recent PVMaT solicitation [1,2] are just now being reported in the companies' annual reviews. Some of the more noteworthy achievements are described in the following brief summaries of subcontractor activities.

Ascension Technology, Inc. (ATI) is working on the SunSine ${ }^{\mathrm{TM}} 300$ AC Module for improved performance, lower cost, and improved manufacturability. The goals are to 
achieve a $40 \%-50 \%$ SunSine $^{\mathrm{TM}}$ cost reduction, reduce the overall footprint of the unit, increase peak efficiency, achieve peak power operation of $355 \mathrm{~W}_{\mathrm{ac}}$, and establish a production capability of 5000 units per year with less than $0.1 \%$ failure at startup. ATI presently has a design to achieve this cost reduction, but product testing is just being initiated.

ASE Americas Inc. is improving process integration and implementing statistical process control and data systems. The improvements are directed at reducing yield losses in areas of electrical and mechanical performance and reducing chemical waste. This effort includes work in laser-cutting technology to increase speed for cutting wafers and R\&D to ensure a stronger edge-defined, film-fed growth (EFG) wafer and improve cell processing to produce $15 \%$ efficient solar cells.

AstroPower, Inc., is improving their flexible manufacturing system for their Silicon-Film ${ }^{\mathrm{TM}}$ solar cells. During the past year, they have extended their continuous processing from Silicon-Film ${ }^{\mathrm{TM}}$ sheet fabrication to solar cell fabrication steps. Their goals are to achieve large-area (900$\mathrm{cm}^{2}$ ), 12\%-efficient (10.8-W) solar cells.

Crystal Systems, Inc., is working on the production of solar-grade feedstock silicon by refining liquid metallurgicalgrade (MG) silicon at low cost. The approach is based on thermo-chemical refining techniques and the Heat Exchanger Method $(\mathrm{HEM})^{\mathrm{TM}}$. Developing and implementing this upgraded solar-grade silicon feedstock is expected to result in significant labor cost savings and increased throughput, with the production cost goal of solar-grade silicon to be less than $\$ 20 / \mathrm{kg}$.

Energy Conversion Devices, Inc. (ECD) is performing manufacturing $\mathrm{R} \& \mathrm{D}$ to: achieve more accurate temperature controlling and monitoring for the production of high-efficiency solar cells; develop a set of in-line, real-time, material-quality monitoring systems; demonstrate the feasibility of using $\mathrm{Zn}$ metal targets to prepare $\mathrm{ZnO}$ layers for high-performance back-reflectors; and redesign the internal hardware for a-Si intrinsic layer (i-layer) deposition chambers.

Evergreen Solar, Inc., is improving their string ribbon crystal-growth process through reductions in labor and material costs and in capital costs of additional furnaces, through increased automation and increased efficiency. They have increased their cell efficiency by $5 \%$ and increased their run length by a factor of two. And they have reduced hot-zone consumable costs by $60 \%$.

Global Solar Energy, L.L.C., is performing R\&D to refine an all-laser, multiple-beam, high-speed scribing method for all copper indium gallium diselenide (CIGS) PV layers, develop a process for ink-jet printing to replace screen printing for insulating scribed areas, and develop and integrate a highrate CIGS deposition process for a moving flexible substrate onto their manufacturing line. They have reported the demonstration of ink-jet deposition of insulating material on test substrates with results that compare favorably with processes such as screen printing.

Omnion Power Engineering Corporation plans to complete design enhancements to produce Series 25001 - and $2-\mathrm{kW}$ inverters that are easily manufactured and are suitable for use in residential applications. These inverters will be for utility-interactive applications and meet design requirements for high-volume production (5000 units/year). This product will use the transformerless, phase-leg topology of the Omnion Series 2200, but with enhancements for a larger input voltage range of 180 to $500 \mathrm{~V}_{\mathrm{dc}}$.

PowerLight Corporation is boosting their PV manufacturing capability by improving the sequential integration of semi-automated and automated component stations in the existing manufacturing line for their PowerGuard $^{\mathrm{R}}$ rooftop product. They have reported achieving a reduction from $\$ 5.80 / \mathrm{W}$ to $\$ 4.80 / \mathrm{W}$ total costs for installed PV systems of $250 \mathrm{~kW}$ or larger. In addition, they have increased their production capacity from 5 to $20 \mathrm{MW}$ per year.

Siemens Solar Industries is concentrating their research on the development and integration of new optimized cell fabrication processes into their manufacturing line for the production of $17 \%$-efficient, $125-\mu \mathrm{m}$-thick cells. They are also developing a large-area cell production capability for 200mm-diameter, 4.5-watt prototype solar cells and low-cost prototype modules.

Solar Cells, Inc. (SCI), which has recently become a partner with True North Partners and is now working as First Solar, LLC, is developing, designing, and implementing an improved ethylene vinyl acetate (EVA) lamination process, potting procedure, and scribing technique for the SCI cadmium telluride (CdTe) module production line. They have developed a 2 minute per module lamination process with a $90 \%$ reduction in both capital equipment and labor costs, and they have demonstrated a $1,080 \mathrm{ft}^{2} /$ hour coating speed on a 2.3-mm thick substrate.

Solarex Corporation is performing R\&D in several parallel areas. They are working with a lower-tier subcontractor to develop a process to produce silicon feedstock from commercial-grade $\mathrm{H}_{2} \mathrm{SiF}_{6}$. They are also refining production-line process areas for improved product and materials handling to increase production-line yield and reduce labor costs. Solarex is studying process measurement and control in their production line and reducing rework by implementing an improved information system.

Spire Corporation is addressing automated photovoltaic module assembly. They are developing a series of automated, flexible systems, including 1) an integrated module-edge processing system, combining automated edge trimming, edge sealing, and framing processes, 2) an automated junction-box installation system, 3) a final module test system combining high-voltage isolation testing and performance testing in a SPI-SUN SIMULATOR ${ }^{\mathrm{TM}}$, and 4) an 
automated buffer storage system. The systems will be capable of assembling modules made with either crystalline-silicon solar cells or thin-film solar-cell laminates.

Utility Power Group, Inc. (UPGI) is addressing the development of a PV Array Power Unit for roof-top applications. The roof-top system will consist of a PV array, an $8-12 \mathrm{~kW}$ Power Unit, and an optional Energy Storage Unit. The power conditioning components will be designed to support a variety of laminates, including the Siemens, Solarex a-Si, and Evergreen Solar products.

\section{Overall PVMaT Status}

\section{Project Funding by PV Technology}

Fig. 1 shows the total commitment, by technology, for all past and present subcontracts, including projections to complete the active projects. Almost half of the funding has been for crystalline silicon. This is not surprising because PVMaT has been designed to support $R \& D$ that maximizes the impact for reducing manufacturing cost and increasing manufacturing capacity. To date, the more mature technologies show a quicker, larger response due to direct application of $\mathrm{R} \& \mathrm{D}$ results to existing manufacturing lines and, therefore, have received the most funding.

\begin{tabular}{|l|c|c|}
\hline \multicolumn{1}{|c|}{ Technology } & $\begin{array}{c}\text { DOE } \\
\text { Funds } \\
\mathbf{( \$ K )}\end{array}$ & $\begin{array}{c}\text { Technology } \\
\mathbf{( \% )}\end{array}$ \\
\hline Amorphous Silicon & 20,184 & 20.9 \\
\hline CdTe, CIGS & 13,879 & 14.4 \\
\hline Concentrators & 6,162 & 6.4 \\
\hline Crystalline Silicon & 42,687 & 44.2 \\
\hline Generic/BOS/Systems & 13,624 & 14.1 \\
\hline Totals & $\mathbf{9 6 , 5 3 6}$ & $\mathbf{1 0 0 . 0}$ \\
\hline
\end{tabular}

Fig. 1 PVMaT funding by technology (includes commitments).

\section{Industry Cost-Sharing}

The PVMaT cost-sharing to date has averaged just over $42 \%$. Fig. 2 shows cost-sharing for the individual solicitations. The last two solicitations have been divided into parts that separate the module manufacturing R\&D from the BOS and system efforts. We have done this because the BOS and system activities tend to be performed by smaller companies with lower cost-sharing requirements.

\begin{tabular}{|l|c|c|c|}
\hline Year/Solicitation Area & $\begin{array}{c}\text { NREL } \\
\text { Share } \\
\mathbf{( \$ K )}\end{array}$ & $\begin{array}{c}\text { Subs. } \\
\text { Share } \\
\mathbf{( \$ K )}\end{array}$ & $\begin{array}{c}\text { \% } \\
\text { Cost } \\
\text { Share } \\
\text { by } \\
\text { Subs. }\end{array}$ \\
\hline $\begin{array}{l}\text { 1992: Process-Specific } \\
\text { R\&D }\end{array}$ & 30,738 & 21,316 & 40.9 \\
\hline $\begin{array}{l}\text { 1992: Generic/Teamed } \\
\text { Research }\end{array}$ & 2,220 & 752 & 25.3 \\
\hline $\begin{array}{l}\text { 1993: Process-Specific } \\
\text { R\&D }\end{array}$ & 13,384 & 14,557 & 52.1 \\
\hline $\begin{array}{l}\text { 1995: Product-Driven } \\
\text { Systems \& Comp. } \\
\text { Manufacturing }\end{array}$ & 5,343 & 1,812 & 25.3 \\
\hline $\begin{array}{l}\text { 1995: Product-Driven } \\
\text { Module Manufacturing }\end{array}$ & 14,290 & 10,141 & 41.5 \\
\hline $\begin{array}{l}\text { 1998: Systems \& Comp. } \\
\text { Manufacturing }\end{array}$ & 2,692 & 1,550 & 36.5 \\
\hline $\begin{array}{l}\text { 1998: Module } \\
\text { Manufacturing }\end{array}$ & 11,853 & 9,010 & 43.2 \\
\hline Totals & $\mathbf{8 0 , 5 2 0}$ & $\mathbf{5 9 , 1 3 8}$ & $\mathbf{4 2 . 3}$ \\
\hline
\end{tabular}

Fig. 2 PVMaT cost shares (includes costs only through FY1999)

Recapturing the Government/Industry Investment

Fig. 3 presents a measure of the benefits of PVMaT to government, industry, and the public. Reduced costs resulting from PVMaT can appear either as reduced prices to customers (the public) or as increased profits to industry. These "profits" could also appear as reduced losses or increased investments.

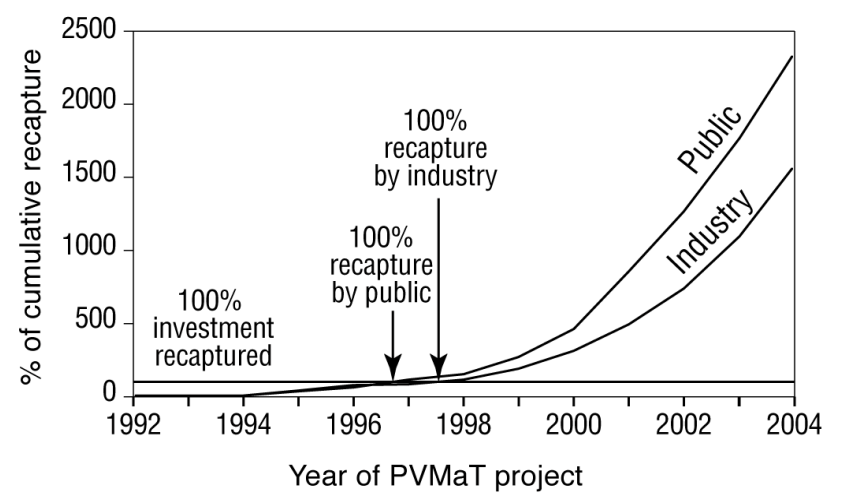

Fig. 3 Recapture of PVMaT Research Funding

These data represent PVMaT funding through 1998. The graph shows the percentage of cumulative "recapture" versus the year of the PVMaT project. The curves are based on data from 16 industrial PVMaT subcontractors. The reduced 
costs from PVMaT improvements are split into public benefits and industry profits. First, the data were convolved with the individual companies' manufacturing volume (history) and capacity (future projection) data. The resulting values were normalized, i.e., public benefits were divided by funding provided by the government, and company profits were divided by cost-sharing provided by the company. Results, calculated on a yearly basis using cumulative values, are called "percentage of cumulative recapture." Thus, "recapture" is a measure of recovered funds compared to investments in the PVMaT project.

At $100 \%$ cumulative recapture, the industry and/or public has recovered all funds invested in the project. The two arrows indicate that the public began exceeding the recovery of its investment by late 1996 and that industry recaptured the funds it had spent by late 1997. The public benefits from the reduced prices on PV products for everyone and, thereby, recovers government funds spent on research. By 2004, industry will have recovered 15 times its initial investment, and the public will have benefited by a factor of 23 .

\section{Cost and Capacity Improvements}

Fig. 4 shows total manufacturing capacity versus average direct costs for module manufacturing. The plot is based on data from the ten 1998 industrial participants who have active production lines. The value of "average module manufacturing costs" is a weighted average based on the manufacturing capacity of each of these participants. As seen for the ten manufacturers, PV manufacturing capacity has increased by more than a factor of five since 1992, from 13.1 to 73.3 megawatts. Additionally, the weighted-average cost for manufacturing PV modules has been reduced by $29 \%$, from \$4.08 to \$2.91 per peak watt. Projections through 2004 indicate a steady decline to an average module manufacturing cost of $\$ 1.25$ per peak watt at just over 500 megawatts capacity.

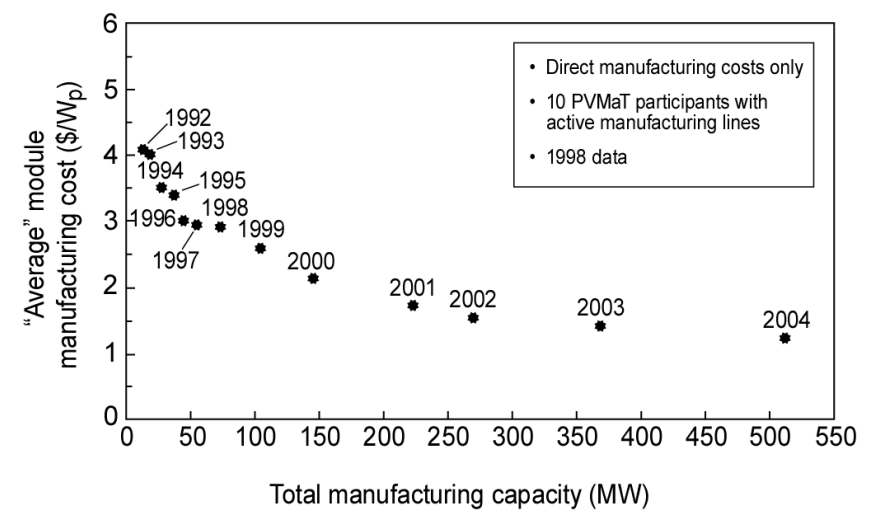

Fig. 4 PVMaT Manufacturing Cost/Capacity
Areas for Future R\&D

Many areas of manufacturing R\&D still exist that are important for continuing to reduce the cost of photovoltaics. Three of the most important areas are yield, throughput, and the ability to produce products that possess the higher solar conversion efficiencies demonstrated in the laboratory. The path to achieving better products runs through the manufacturing lines. Better, more reliable, and faster processes are required, and these in turn require improvements such as more intelligent processing, in-situ diagnostics, and less expensive methods of assembly. In addition, each specific PV technology has its own critical areas that require additional R\&D. PVMaT results show broad-based manufacturing R\&D is essential for building on the continued advances provided by basic and applied R\&D elements of the National Photovoltaics Program and for improving PV technology as a whole.

\section{Conclusions}

In the past six years, the weighted-average cost for manufacturing PV modules by ten PVMaT participants has been reduced by $29 \%$, from $\$ 4.08$ to $\$ 2.91$ per peak watt. The benefits of this cost reduction to both manufacturers and customers have more than repaid the costs associated with manufacturing R\&D incurred under PVMaT. Areas for further study offer the promise of additional cost reduction and continue to be a fruitful area for a shared investment by government and industry.

\section{Acknowledgments}

This work is supported under DOE Contract No. DEAC36-98-GO10337 with NREL, a national laboratory managed by Midwest Research Institute, Battelle, and Bechtel. Many people have contributed to the development and implementation of the Photovoltaic Manufacturing Technology project and to the R\&D efforts carried out in this program. The authors thank each of them and recognize that this paper represents their work.

\section{References}

1. C.E. Witt, R.L. Mitchell, H.P. Thomas, M.I. Symko, R. King, and D.S. Ruby, "Manufacturing Improvements in the Photovoltaic Manufacturing Technology (PVMaT) Project," Proceedings of the 2nd World Conf. on PV Solar Energy Conversion, Vienna, Austria, July, 1998.

2. H.P. Thomas, B. Kroposki, P. McNutt, C.E. Witt, W. Bower, R. Bonn, and T.D. Hund, "Progress in Photovoltaic System Component Improvements," Proceedings of the 2nd World Conf. on PV Solar Energy Conversion, Vienna, Austria, July, 1998. 


\section{REPORT DOCUMENTATION PAGE}

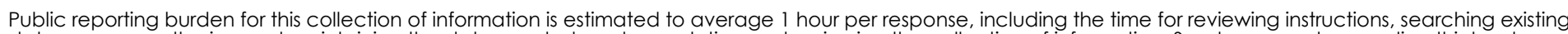

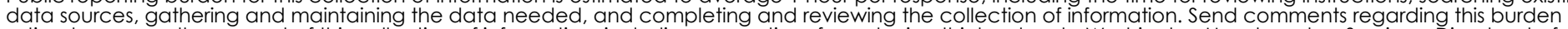

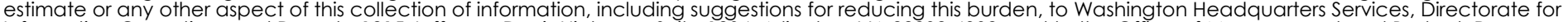

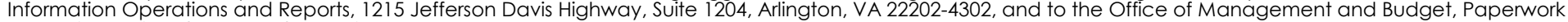
Reduction Project (0704-0188), Washington, DC 20503.
1. AGENCY USE ONLY (Leave blank)
2. REPORT DATE
November 1999
3. REPORT TYPE AND DATES COVERED
Conference paper

4. TITLE AND SUBTITLE

Current Status and Future Prospects for the PVMaT Project

6. AUTHOR(S)

C.E. Witt, R.L. Mitchell, M. Symko-Davies, H.P. Thomas, R. King, D.S. Ruby

7. PERFORMING ORGANIZATION NAME(S) AND ADDRESS(ES)

7. PERFORMING ORGANIZATION NAME(S) AND ADDRESS(ES)

9. SPONSORING/MONITORING AGENCY NAME(S) AND ADDRESS(ES)

National Renewable Energy Laboratory

1617 Cole Blvd.

Golden, CO 80401-3393

5. FUNDING NUMBERS

C

TA: PV906101

8. PERFORMING ORGANIZATION REPORT NUMBER

10. SPONSORING/MONITORING AGENCY REPORT NUMBER

CP-520-26922

11. SUPPLEMENTARY NOTES

12a. DISTRIBUTION/AVAILABILITY STATEMENT

National Technical Information Service

U.S. Department of Commerce

5285 Port Royal Road

Springfield, VA 22161

12b. DISTRIBUTION CODE

13. ABSTRACT (Maximum 200 words)

The goals of the Photovoltaic Manufacturing Technology project (PVMaT) are to help the U.S. PV industry improve photovoltaic manufacturing processes and equipment; accelerate manufacturing cost reductions for PV modules, balance-of-systems components, and integrated systems; increase commercial product performance and reliability; and enhance the investment opportunities for substantial scale-ups of U.S.-based PV manufacturing plant capacities. PVMaT is in its ninth year of implementation, and subcontracts have been completed from four solicitations for R\&D on manufacturing process problems. We are in the second year of subcontracts for a fifth PVMaT solicitation. Based on the latest (1998) data from ten PVMaT industrial participants, the average direct manufacturing cost for these producers has been reduced by $29 \%$ - from $\$ 4.08$ to $\$ 2.91$ per peak watt since 1992 - and there has also been a more than five-fold increase in manufacturing capacity - from 13.1 to 73.3 megawatts. We believe that continuing R\&D on manufacturing processes contributes significantly to expeditious reductions in PV manufacturing costs, and we identify areas for future R\&D.
14. SUBJECT TERMS
photovoltaics ; Photovoltaic Manufacturing Technology ; PVMaT ; R\&D ; cost-sharing

\section{NUMBER OF PAGES}

16. PRICE CODE

17. SECURITY CLASSIFICATION OF REPORT

Unclassified
18. SECURITY CLASSIFICATION OF THIS PAGE Unclassified
19. SECURITY CLASSIFICATION OF ABSTRACT Unclassified
20. LIMITATION OF ABSTRACT

UL 